\title{
How does academic achievement relate to cardiorespiratory fitness, self-reported physical activity and objectively reported physical activity: a systematic review in children and adolescents aged 6-18 years
}

\author{
Adilson Marques, ${ }^{1,2}$ Diana A Santos, ${ }^{1}$ Charles H Hillman, ${ }^{3,4}$ Luís B Sardinha $^{1}$
}

${ }^{1}$ Centro Interdisciplinar de Estudo da Performance Humana, Faculdade de Motricidade Humana, Universidade de Lisboa, Lisboa, Portugal

${ }^{2}$ Centro de Investigação em Saúde Pública, Escola Nacional de Saúde Pública, Universidade Nova de Lisboa, Lisboa, Portugal ${ }^{3}$ Department of Psychology, Northeastern University, Boston, Massachusetts, USA

${ }^{4}$ Department of Health Sciences, Northeastern University, Boston, Massachusetts, USA

\section{Correspondence to} Professor Luís B Sardinha, Faculdade de Motricidade Humana, Universidade de Lisboa, Estrada da Costa, 1499002 Cruz-Quebrada, Portugal; Isardinha@fmh.ulisboa.pt

Accepted 12 September 2017

\section{(a) CrossMark}

To cite: Marques $A$ Santos DA, Hillman CH, et al. Br J Sports Med Published Online First: [please include Day Month Year]. doi:10.1136/ bjsports-2016-097361

\begin{abstract}
Objective This report aimed to systematically review the evidence for a differential association between objective and self-reported physical activity and cardiorespiratory fitness on academic achievement. Design Systematic review.

Data sources Studies were identified from searches in Embase, Education Resources Information Center, PubMed, PsycINFO, SPORTdiscus and Web of Science databases from January 2000 to December 2016. Eligibility criteria for selecting studies Eligibility criteria included cross-sectional, longitudinal and interventional study designs. Outcomes included students' school grade or a standardised test or measure of academic achievement. Explanatory variables were cardiorespiratory fitness and objective and self-reported physical activity. Inclusion criteria included school-aged children and adolescents aged18 years (or students from primary to secondary school when student's participants age was not described) and articles published in English, Portuguese or Spanish.
\end{abstract}

Results A total of 51 articles met inclusion criteria: 41 cross-sectional, 2 intervention and 8 longitudinal studies. Results from 11 studies were inconsistent regarding the relationship between objectively measured physical activity and academic achievement. Ten of the 16 articles reported positive associations between self-reported physical activity and academic achievement. From the 22 studies that analysed the relationship between cardiorespiratory fitness and academic achievement, it was verified that they all generally support the beneficial effect of cardiorespiratory fitness on students' academic achievement.

Conclusion Higher cardiorespiratory fitness may be important to enhance children and adolescents' health and, additionally, academic achievement. Due to a lack of consensus across studies, methodological issues associated with the assessment of physical activity should be considered when investigating physical activity and academic achievement.

\section{INTRODUCTION}

Physical activity and cardiorespiratory fitness are associated with a variety of health benefits in children and adolescents. ${ }^{1-3}$ In addition to the benefits on physical and mental health, studies in neuroscience have shown that physical activity and cardiorespiratory fitness are related to brain structure and function. ${ }^{4}$ The pathways by which they may change brain structure and function include: (1) alterations in thickness of grey matter in specific cortical regions ${ }^{5}$ and integrity of white matter tracts that support executive function ${ }^{6}$; (2) alterations in brain plasticity that change the structure of the neuron and strengthen its signalling capability ${ }^{7}$; and (3) improvements in attention, ${ }^{9}$ memory ${ }^{10} 11$ and executive function. ${ }^{12}$ Accordingly, it is expected that the benefits of cardiorespiratory fitness and physical activity on brain structure, function, plasticity and cognition might translate to improvement in academic achievement. ${ }^{5}$

There is a growing body of literature that has examined the relationship between physical activity and cardiorespiratory fitness with academic achievement in children and adolescents. ${ }^{13-15}$ Although most studies have shown that physical activity and cardiorespiratory fitness are associated with enhanced academic achievement, ${ }^{13}{ }^{14}$ the literature has not yet reached consensus, ${ }^{15}$ as there are some studies showing no associations ${ }^{16}{ }^{17}$ or negative associations ${ }^{18} 19$ between physical activity or cardiorespiratory fitness with academic achievement.

These inconsistent results may occur since physical activity can be assessed objectively or subjectively and, moreover, physical activity and cardiorespiratory fitness may not have the same relation to academic achievement. In fact, self-reported measures tend to overestimate physical activity when compared with accelerometry. ${ }^{20}{ }^{21}$ Furthermore, mean time spent per day in moderate-to-vigorous physical activity (MVPA) can differ by over $100 \mathrm{~min}$ when comparing questionnaires and accelerometers (146 min/day using a questionnaire vs $24 \mathrm{~min} /$ day using an accelerometer). ${ }^{21}$ Thus, separating investigations of objectively measured and self-reported physical activity and cardiorespiratory fitness would help to clarify the associations between physical activity and cardiorespiratory fitness with academic achievement. We aimed to systematically review the evidence from 2000 to 2016 of an association between objective and self-reported physical activity and cardiorespiratory fitness with academic achievement in school-aged children and adolescents. 


\section{METHODS}

This systematic review was performed in accordance with the Preferred Reporting Items for Systematic Reviews and Meta-Analysis (PRISMA) guidelines ${ }^{22}$ and the association of physical activity and academic achievement protocol for systematic reviews and meta-analysis. ${ }^{23}$ The protocol was registered on the International Prospective Register of Systematic Reviews database under the number CRD42016043204.

\section{Inclusion criteria}

Primary source articles published from 2000 to 2016 in peer-reviewed journals were eligible for inclusion if data were presented on the relationship among physical activity, cardiorespiratory fitness and academic achievement. Specific eligibility criteria included the following: (1) cross-sectional, longitudinal and interventional study designs (study design criterion); (2) outcomes included students' school grade or a standardised test or measure of academic achievement (outcome measure criterion); (3) cardiorespiratory fitness, objective and self-reported physical activity and academic achievement (relationship criterion); (4) school-aged children and adolescents aged 6-18 years, or students from primary, elementary and secondary school when participants' age was not reported (participants criterion); (5) articles published in English, Portuguese or Spanish (language criterion); (6) articles were excluded if they did not meet inclusion criteria or did not include findings related to the inclusion criteria (ie, measured cardiorespiratory fitness and physical activity but failed to compare with academic achievement) (exclusion criteria); and (7) studied with a sample size below $30(n<30)$ were also excluded, ${ }^{24}$ because the measure of physical activity (subjective and objective) in small samples is subject to a greater variability.

\section{Search strategy and study selection}

Studies were comprehensively identified by searching in electronic databases of peer-reviewed articles published from January 2000 to December 2016. The last search was conducted on 17 January 2017. The search was applied to Embase, Education Resources Information Center, PubMed, PsycINFO, SPORTdiscus and Web of Science. Investigations using accelerometers started to rise in the beginning of the millennium. ${ }^{25}$ To avoid any secular trends in the outcomes and explanatory variables (eg, subjective vs objective outcomes), the selection criteria was restricted to studies published since 2000 , ensuring that all independent variables were analysed within the same time frame.

Search terms were defined through discussion among the research team and were used in each database to identify potential articles with abstracts for review. The search terms were as follows: 'physical activity' OR 'physical education' OR 'sport' OR 'athletic participation' OR 'exercise' OR 'fitness' OR 'aerobic' AND 'academic achievement' OR 'academic performance' OR 'academic attainment' OR 'academic skills' OR 'academic ability' OR 'performance at school' OR 'cognitive performance'.

Retrieved titles and abstracts were independently assessed for eligibility for inclusion in the review by two authors (AM and DAS) and coded as 'yes', 'no' or 'maybe'. Duplicate entries were manually removed. Relevant articles were then retrieved for complete review and analysis. The same two authors reviewed the full text of potential studies, and decisions to include or exclude studies in the review were made by consensus. A Microsoft Excel spread sheet was developed to track eligibility status. Authors of articles lacking information were contacted for clarification.

\section{Data extraction and harmonisation}

A data extraction form was developed based on the PRISMA statement. $^{22}$ Relevant data were extracted from each manuscript by one author (AM), and coding was verified by the other authors (DAS and LBS). Disagreements were resolved by discussion among authors. Data extracted from each article included study information (design, country, sample size, groups compared and cardiorespiratory and/or physical activity groups/ interventions), participant characteristics (age, sex and school grade), cardiorespiratory fitness and physical activity assessment method, academic achievement assessment method and results.

\section{Study quality and risk of bias}

Study quality was assessed using checklist criteria from the Quality Assessment Tool for Quantitative Studies. ${ }^{26}$ The checklist was adapted to evaluate both experimental and observational studies. The checklist comprises 19 items, assessing eight key methodological domains (sections): selection bias, study design, confounders, blinding, data collection methods, withdrawals and dropouts, intervention integrity and analyses. Each section was classified as strong, moderate and weak methodological quality. Then, a global rating is determined based on the scores of each component. Two researchers rated the articles in each domain and in overall quality. Discrepancies were resolved by consensus. Studies were not excluded based on methodological quality.

\section{Synthesis of results}

This systematic review analysed the relationship between objectively measured and self-reported physical activity, cardiorespiratory fitness and academic achievement in children and adolescents. Although academic achievement was measured through school grades or standardised test scores, the articles were not grouped by the outcome variable. However, since inconsistent study results may be due to the fact that physical activity can be assessed objectively or subjectively and that physical activity and cardiorespiratory fitness may not have the same effect on academic achievement, articles were grouped by the exposure variable (cardiorespiratory fitness, objectively assessed physical activity and subjectively assessed physical activity).

Considerable heterogeneity existed across studies for several parameters. These parameters included the following: participant characteristics, academic achievement measures and cardiorespiratory and physical activity assessment methods. The details for each study, including design, measures, participant characteristics and sample size, study quality and results, are presented in a consistent manner.

\section{RESULTS}

\section{Literature search}

The flow of citation through the systematic review process is depicted in figure 1 . The systematic literature search yielded a total of 778 potentially relevant publications. After excluding duplicates $(n=463), 315$ publications were screened for inclusion in the review, and a total of 218 articles were rejected at title and abstract level. Consequently, 97 potentially relevant citations were obtained, of which 51 articles were identified as relevant. 


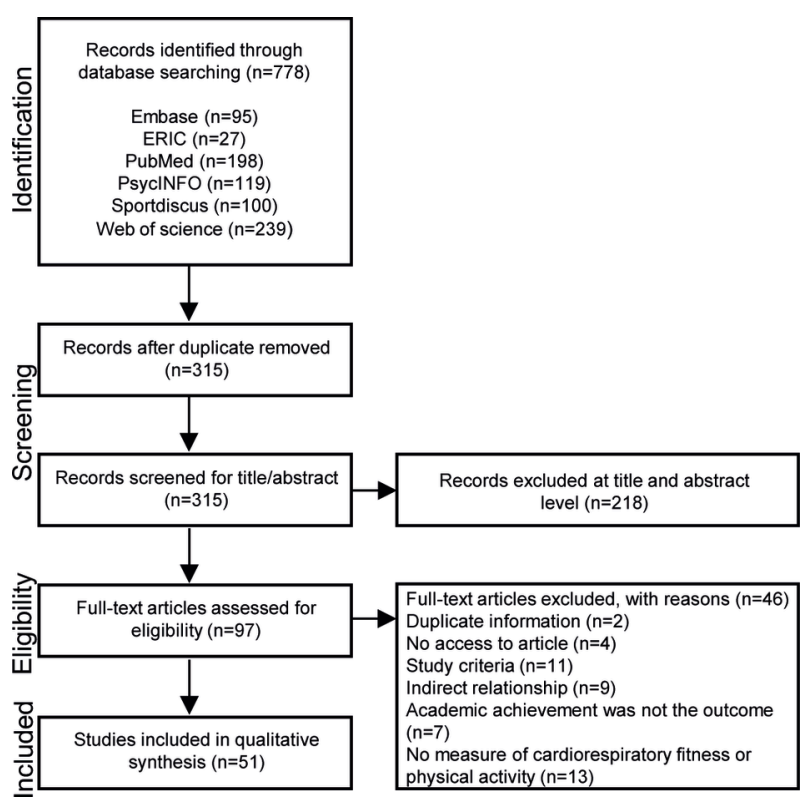

Figure 1 ERIC, Education Resources Information Center.

\section{Study characteristics}

The study characteristics are summarised in table 1 . Of the 51 included studies, 41 were cross-sectional, 2 intervention and 8 longitudinal. In half of the studies, the outcome variable (academic achievement) was the students' marks at the school level, and standardised tests were used for the other half. Most studies analysed the relationship between academic achievement with cardiorespiratory fitness, followed by the relationship with self-reported physical activity and lastly objectively measured physical activity. Five studies used both cardiorespiratory fitness and objective physical activity as independent variables, and one study used cardiorespiratory fitness and self-reported physical activity. Most studies took place in Europe $(n=20)$ or North America $(n=17)$, and the remainder studies were from Africa $(n=1)$, Asia $(n=5)$, Oceania $(n=2)$ and South America $(n=6)$. Three studies were considered to be of weak methodological quality, 14 of moderate quality and the other 34 of strong quality.

\section{Principal findings}

Objectively measured physical activity and academic achievement

The description of the studies reporting the relationship between objectively measured physical activity and academic achievement is presented in table 2 . The results from the 11 studies that were screened $^{17} 19$ 27-35 were inconsistent regarding the relationship between objectively measured physical activity and academic achievement. Four studies of strong quality provided partial support for a positive relationship. ${ }^{27} 283135$ Vigorous physical activity (VPA) was associated with academic achievement in girls, after controlling for confounding factors, but no significant association was observed in boys. ${ }^{28}$ In a longitudinal study, the percentage of time spent in MVPA predicted greater performance in English assessments across sexes but not in math and science. ${ }^{27}$ Higher MVPA was related to higher academic achievement in writing and numeracy but not in reading and spelling. ${ }^{31}$ In an intervention study, there was a significant effect of physical activity on numeracy among the children who initially performed the most poorly on the test, but no significant effect of the intervention on academic achievement measures was observed using intention-to-treat analyses. ${ }^{35}$ These studies that partially supported a positive relationship between objectively measured
Table 1 Characteristics of the studies examining potential relationship between CRF, PA and academic achievement

\begin{tabular}{|c|c|}
\hline Characteristics & Number of studies \\
\hline \multicolumn{2}{|l|}{ Study design } \\
\hline Cross-sectional & 41 \\
\hline Intervention & 2 \\
\hline Longitudinal & 8 \\
\hline \multicolumn{2}{|l|}{ Outcome measured } \\
\hline School grade* & 25 \\
\hline Standardised tests & 26 \\
\hline \multicolumn{2}{|l|}{ Independent variable } \\
\hline Only CRF & 23 \\
\hline Only PA objective & 9 \\
\hline Only PA self-reported & 13 \\
\hline CRF and PA objective & 1 \\
\hline CRF and PA self-reported & 5 \\
\hline \multicolumn{2}{|l|}{ Sample characteristics } \\
\hline \multicolumn{2}{|l|}{ Country } \\
\hline Australia & 2 \\
\hline Brazil & 2 \\
\hline Canada & 1 \\
\hline Chile & 3 \\
\hline China/Taiwan & 3 \\
\hline Denmark & 1 \\
\hline Finland & 4 \\
\hline Germany & 1 \\
\hline Iceland & 1 \\
\hline Iran & 1 \\
\hline Netherlands & 2 \\
\hline Norway & 1 \\
\hline Portugal & 2 \\
\hline South Africa & 1 \\
\hline South Korea & 1 \\
\hline Spain & 4 \\
\hline Sweden & 1 \\
\hline UK & 3 \\
\hline USA & 16 \\
\hline \multicolumn{2}{|l|}{ Sex } \\
\hline Only boys & 1 \\
\hline Boys and girls & 50 \\
\hline \multicolumn{2}{|l|}{ Age group } \\
\hline$\leq 10$ years & 9 \\
\hline$>10$ years & 34 \\
\hline$\leq 10$ and $<10$ years & 8 \\
\hline \multicolumn{2}{|l|}{ Study quality } \\
\hline Weak & 3 \\
\hline Moderate & 14 \\
\hline Strong & 34 \\
\hline
\end{tabular}

physical activity and academic achievement were performed in different countries, with sample sizes ranging from 232 to 4755 children and adolescents. In one study of strong quality and with a large sample, physical activity was negatively associated with all academic achievement indicators after adjusting for potential confounders, such as adiposity and fitness. ${ }^{19}$ However, the strength of the association was weak in all activity intensities. In the other six studies, no significant association was found between physical activity and academic achievement. ${ }^{1729} 3032-34$ 
Downloaded from http://bjsm.bmj.com/ on October 16, 2017 - Published by group.bmj.com

Review

Table 2 Description of the studies reporting the relationship between objectively measured PA and AA in children and adolescents

\begin{tabular}{|c|c|c|c|c|c|}
\hline $\begin{array}{l}\text { Source and study } \\
\text { quality }\end{array}$ & $\begin{array}{l}\text { Study design and sample } \\
\text { characteristics (country, } \\
\text { age range/mean, grade, sex, } \mathrm{n} \text { ) }\end{array}$ & Outcome measured & PA measure & Adjustments for confounders & Main results \\
\hline Kwak et $a^{28} \dagger$ & $\begin{array}{l}\text { Cross-sectional } \\
\text { Sweden, } 16 \text { y, grade } 9 \text {, } \\
\text { boys and girls, } n=232\end{array}$ & School grades & Accelerometer & $\begin{array}{l}\text { Age, pubertal phase, sum of skinfolds, } \\
\text { mother's education, family structure and } \\
\text { parental monitoring. }\end{array}$ & $\begin{array}{l}\text { VPA was associated with AA in girls, after } \\
\text { controlling for confounding factors. } ₹ \\
\text { LPA and MPA were not associated with AA } \\
\text { in boys. ( } \pm \text { ) LPA, MPA and VPA were not } \\
\text { associated with AA in boys.§ }\end{array}$ \\
\hline LeBlanc et $a \beta^{30} \dagger$ & $\begin{array}{l}\text { Cross-sectional } \\
\text { USA, } 10.5 y \text {, grades } 4-6 \text {, } \\
\text { boys and girls, } n=261\end{array}$ & Standardised annual test & Accelerometer & Age, sex and SES. & MPA was not associated with AA.§ \\
\hline Booth et $a l^{27} \dagger$ & $\begin{array}{l}\text { Longitudinal } \\
\text { UK, } 11 \text { y, boys and girls, } n=4755\end{array}$ & $\begin{array}{l}\text { Compulsory nationally } \\
\text { administered tests }\end{array}$ & Accelerometer & $\begin{array}{l}\text { Age, birth weight, gestation, age of mother } \\
\text { at delivery, mother's oily fish intake, mother } \\
\text { smoking habits in the first } 3 \text { months of } \\
\text { pregnancy, BMI Z score, pubertal stage, } \\
\text { ethnicity, maternal educational, occupational } \\
\text { social class and total PA. }\end{array}$ & 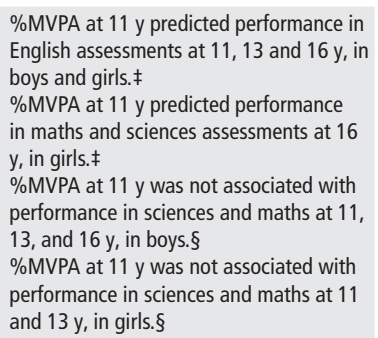 \\
\hline Lambourne et $a^{29} \dagger$ & $\begin{array}{l}\text { Cross-sectional } \\
\text { USA, } 7.6 \text { y, grades } 2-3 \text {, } \\
\text { boys and girls, } n=401\end{array}$ & $\begin{array}{l}\text { Weschsler Individual } \\
\text { Achievement Test-Third } \\
\text { Edition }\end{array}$ & Accelerometer & $\begin{array}{l}\text { Sex, grade, BMI, mother's education level } \\
\text { and household income. }\end{array}$ & $\begin{array}{l}\text { Total PA was associated with math } \\
\text { achievement (partially mediated by } \\
\text { fitness). } \\
\text { Total PA was not associated with reading } \\
\text { or spelling.§ }\end{array}$ \\
\hline Syväoja et $a \beta^{33} \dagger$ & $\begin{array}{l}\text { Cross-sectional } \\
\text { Finland, } 12.2 \mathrm{y} \text {, grades } 5-6 \text {, } \\
\text { boys and girls, } n=277\end{array}$ & School grades & Accelerometer & $\begin{array}{l}\text { Sex, children's learning difficulties, highest } \\
\text { level of parental education and amount of } \\
\text { sleep. }\end{array}$ & $\begin{array}{l}\text { MVPA was not associated with grade } \\
\text { point average.§}\end{array}$ \\
\hline Esteban-Cornejo et a ${ }^{19} \dagger$ & $\begin{array}{l}\text { Cross-sectional } \\
\text { Spain, } 10.5 \mathrm{y}, \\
\text { boys and girls, } n=1778\end{array}$ & School grades & Accelerometer & $\begin{array}{l}\text { Sex, age, city, maternal education, birth } \\
\text { weight, gestational age, BMI and z-score } \\
\text { values computed from CRF and motor fitness } \\
\text { tests. }\end{array}$ & $\begin{array}{l}\text { MPA, VPA and MVPA were inversely } \\
\text { associated with all AA indicators. } \emptyset\end{array}$ \\
\hline Hansen et $a l^{17} \dagger$ & $\begin{array}{l}\text { Cross-sectional } \\
\text { USA, } 7.8 y \text {, } \\
2-3 \text { boys and girls, } n=687\end{array}$ & $\begin{array}{l}\text { Standardised composite } \\
\text { academic test }\end{array}$ & Accelerometer & $\begin{array}{l}\text { Sex, grade, race, ethnicity, mother's } \\
\text { education level, household income and BMI. }\end{array}$ & $\begin{array}{l}\text { Total PA was not significantly correlated } \\
\text { with AA, either linearly or non-linearly.§}\end{array}$ \\
\hline Van Dijk et $\left.a\right|^{34} \dagger$ & $\begin{array}{l}\text { Cross-sectional } \\
\text { Netherlands, } 13 \text { y, grades } 7-9 \text {, } \\
\text { boys and girls, } n=255\end{array}$ & School grades & Accelerometer & $\begin{array}{l}\text { Sex, nationality, grade, school level, SES, BMI, } \\
\text { CRF, pubertal phase, depressive symptoms } \\
\text { and self-esteem. }\end{array}$ & $\begin{array}{l}\text { Considering the overall sample, weekly } \\
\text { volume of total PA and MVPA was not } \\
\text { associated with AA.§ } \\
\text { In grade } 7 \text { students, weekly volume of } \\
\text { total PA and MVPA were negatively } \\
\text { associated with AA, and MVPA was also } \\
\text { negatively associated with mathematics } \\
\text { achievement. } \\
\text { In grade } 9 \text {, weekly volume of total PA and } \\
\text { MVPA were positively associated with } \\
\text { maths performance. } \neq\end{array}$ \\
\hline Maher et $a l^{31} \dagger$ & $\begin{array}{l}\text { Cross-sectional } \\
\text { Australia, } 10.2 \mathrm{y} \text {, grade } 5 \text {, } \\
\text { boys and girls, } n=285\end{array}$ & $\begin{array}{l}\text { National Assessment } \\
\text { Program - Literacy and } \\
\text { Numeracy }\end{array}$ & Accelerometer & $\begin{array}{l}\text { Sex, school clustering, MVPA, sedentary } \\
\text { behaviour, BMI z-score, ethnicity, highest } \\
\text { household education, household income, } \\
\text { marital status, mothers employment hours } \\
\text { and number of siblings. }\end{array}$ & $\begin{array}{l}\text { Higher MVPA was related with higher AA } \\
\text { in writing and numeracy. } \neq \\
\text { MVPA was not related to language, } \\
\text { reading and } \\
\text { spelling.§ }\end{array}$ \\
\hline Pindus et $a l^{32} \dagger$ & $\begin{array}{l}\text { Cross-sectional } \\
\text { UK, } 8.7 \mathrm{y} \text {, boys and girls, } \mathrm{n}=74\end{array}$ & $\begin{array}{l}\text { Kaufman Test of } \\
\text { Educational Achievement }\end{array}$ & Accelerometer & $\begin{array}{l}\text { Sex, age, IQ, SES, birth weight, diagnosis of } \\
\text { attention deficit hyperactivity disorder and } \\
\text { CRF. }\end{array}$ & $\begin{array}{l}\text { No significant associations were found } \\
\text { between MVPA and AA.§ }\end{array}$ \\
\hline Resaland et $a l^{35} \dagger$ & $\begin{array}{l}\text { Intervention } \\
\text { (7-month cluster RCT) } \\
\text { Norway, } 10.2 \mathrm{y} \text {, } \\
\text { boys and girls, } \mathrm{n}=596\end{array}$ & $\begin{array}{l}\text { Standardised } \\
\text { Norwegian national tests }\end{array}$ & Accelerometer & Sex, SES, PA and AA at baseline. & $\begin{array}{l}\text { No significant overall effect of the } \\
\text { intervention (increasing } 165 \mathrm{~min} / \text { week of } \\
\text { PA) on AA.§ } \\
\text { There was a significant effect on numeracy } \\
\text { among children who initially performed } \\
\text { the poorest. } \neq\end{array}$ \\
\hline
\end{tabular}

tStudy of strong quality.

¥The symbol means that in general there is a positive correlation/association between objective physical activity and academic achievement.

$\S$ The symbol means that in general there is no correlation/association between objective physical activity and academic achievement.

१The symbol means that in general there is a negative correlation/association between objective physical activity and academic achievement.

AA, academic achievement; BMI, body mass index; CRF, cardiorespiratory fitness; LPA, light physical activity, MPA, moderate physical activity; MVPA, moderate-to-vigorous physical activity; PA, physical

activity; SES, socioeconomic status; VPA, vigorous physical activity; y, years.

In the three studies performed with children under 10 years old, ${ }^{172932}$ no significant association was found between physical activity and academic achievement.

\section{Self-report physical activity and academic achievement}

Studies reporting the relationship between self-reported physical activity and academic achievement are presented in table 3. Twelve of the 18 studies that reported positive associations between physical activity and academic achievement included data from several different countries, with sample sizes ranging from 277 to $861 .^{33} 36-46$ Of these 12 studies, three were longitudinal, and physical activity was prospectively associated with academic achievement. ${ }^{394244}$ However, 5 of the 18 studies, two of which had weak methodological quality, did not observe any association. ${ }^{1647-50}$ Nonetheless, in an interventional study, about 50 additional minutes devoted to physical activity per week, 
Table 3 Description of the studies reporting the relationship between self-reported PA and AA in children and adolescents

\begin{tabular}{|c|c|c|c|c|c|}
\hline $\begin{array}{l}\text { Source and study } \\
\text { quality }\end{array}$ & $\begin{array}{l}\text { Study design and sample } \\
\text { characteristics (country, age } \\
\text { range/mean, grade, sex, } n \text { ) }\end{array}$ & Outcome measured & PA measure & Adjustments for confounders & Main results \\
\hline Daley and Ryan $2000^{48 *}$ & $\begin{array}{l}\text { Cross-sectional } \\
\text { UK, } 13-16 \text { y, grades } 8-11 \text {, } \\
\text { boys and girls, } n=232\end{array}$ & School grades & $\begin{array}{l}\text { PA Participation } \\
\text { Questionnaire }\end{array}$ & & $\begin{array}{l}\text { Overall, no significant correlations } \\
\text { were found between PA and } \\
\text { AA. However, weak negative } \\
\text { correlations were found } \\
\text { between total PA and English } \\
\text { scores for those aged 13,14 and } \\
16 \text { years. } \dagger\end{array}$ \\
\hline Dwyer et $a P^{37} \ddagger$ & $\begin{array}{l}\text { Cross-sectional } \\
\text { Australia, } 7-15 \text { y, } \\
\text { boys and girls, } n=7962\end{array}$ & School grades & Questionnaire & $\begin{array}{l}\text { Age, school type, region, \% body } \\
\text { fat, time of sleep, ate before } \\
\text { school, musical train and parental } \\
\text { exercise. }\end{array}$ & $\begin{array}{l}\text { More active students had better } \\
\text { AA. The association between total } \\
\text { PA (minutes of weekly PA) and AA } \\
\text { were weak in girls.§ }\end{array}$ \\
\hline Yu et $a l^{50 *}$ & $\begin{array}{l}\text { Cross-sectional } \\
\text { China, } 10.4 \text { y, grades } 1-4 \text {, } \\
\text { boys and girls, } n=333\end{array}$ & School grades & PAQ-C & & $\begin{array}{l}\text { There was no relationship between } \\
\text { PA level and AA. } t\end{array}$ \\
\hline Ahamed et $a l^{47} \ddagger$ & $\begin{array}{l}\text { Intervention } \\
\text { (16-month cluster RCT) } \\
\text { Canada, } 10.2 \text { y, grades 4-5, } \\
\text { boys and girls, } \mathrm{n}=287\end{array}$ & $\begin{array}{l}\text { Canadian } \\
\text { Achievement Test }\end{array}$ & PAQ-C & Baseline evaluate AA. & $\begin{array}{l}\text { Additional } 10-15 \text { min of school } \\
\text { time devoted to PA did not } \\
\text { compromise AA. } \dagger\end{array}$ \\
\hline Stevens et $a l^{42} \emptyset$ & $\begin{array}{l}\text { Longitudinal } \\
\text { (5-year period) } \\
\text { USA, grade } 5 \text {, } \\
\text { boys and girls, } n=6482\end{array}$ & $\begin{array}{l}\text { Standardised test } \\
\text { scores }\end{array}$ & Questionnaire & SES. & $\begin{array}{l}\text { PA was significantly and positively } \\
\text { related to both mathematics and } \\
\text { reading achievement in boys and } \\
\text { girls. } \S\end{array}$ \\
\hline $\begin{array}{l}\text { Kristjánsson } \\
\text { et } a l^{46} \ddagger\end{array}$ & $\begin{array}{l}\text { Cross-sectional } \\
\text { Iceland, } 14-15 y \text {, grades 9-10, } \\
\text { boys and girls, } n=6345\end{array}$ & School grades & Questionnaire & $\begin{array}{l}\text { Sex, family structure, parental } \\
\text { education and absenteeism }\end{array}$ & $\begin{array}{l}\text { Although the correlation was weak, } \\
\text { increased PA levels was positively } \\
\text { correlated with AA.§ }\end{array}$ \\
\hline Edwards et $a l^{38} \ddagger$ & $\begin{array}{l}\text { Cross-sectional } \\
\text { USA, } 11-13 \text { y, } \\
\text { boys and girls, } n=694\end{array}$ & $\begin{array}{l}\text { Measures of } \\
\text { academic progress }\end{array}$ & Questionnaire & $\begin{array}{l}\text { Sex, meals, fitness measures } \\
\text { and BMI. }\end{array}$ & $\begin{array}{l}\text { Higher measures of academic } \\
\text { progress math scores were } \\
\text { associated with VPA and sport } \\
\text { teams participation.§ }\end{array}$ \\
\hline Morales et al ${ }^{41}$ q & $\begin{array}{l}\text { Cross-sectional } \\
\text { Spain, } 14.7 \text { y, } \\
\text { boys and girls, } n=284\end{array}$ & School grades & IPAQ & & $\begin{array}{l}\text { There was a linear relationship } \\
\text { between MVPA and AA. There is a } \\
\text { trend to stronger correlation when } \\
\text { modelling the } \\
\text { relationship with a quadratic } \\
\text { equation.§ }\end{array}$ \\
\hline $\mathrm{So}^{51} \mp$ & $\begin{array}{l}\text { Cross-sectional } \\
\text { South Korea, } 15.1 \text { y, grades } 7-12 \text {, } \\
\text { boys and girls, } n=75066\end{array}$ & School grades & Questionnaire & $\begin{array}{l}\text { Age, BMI, the parents' education } \\
\text { level and SES. }\end{array}$ & $\begin{array}{l}\text { VPA was positively correlated with } \\
\text { AA in boys, and MPA was positively } \\
\text { correlated with AA in both boys } \\
\text { and girls. } \S \\
\text { However, undertaken } \geq 5 \text { times/ } \\
\text { week, VPA in boys and } \\
\text { strengthening exercises in both } \\
\text { boys and girls were negatively } \\
\text { correlated with AA.** }\end{array}$ \\
\hline Syväoja et $a l^{33} \ddagger$ & $\begin{array}{l}\text { Cross-sectional } \\
\text { Finland, } 12.2 \text { y, grades } 5-6 \text {, } \\
\text { boys and girls, } n=277\end{array}$ & School grades & HBSC & $\begin{array}{l}\text { Sex, children's learning } \\
\text { difficulties, highest level of } \\
\text { parental education and amount } \\
\text { of sleep. }\end{array}$ & $\begin{array}{l}\text { PA was directly associated with AA. } \\
\text { MVPA had an inverse U-shaped } \\
\text { curvilinear } \\
\text { association with grade point } \\
\text { average.§}\end{array}$ \\
\hline Burrows et $a l^{36} \ddagger$ & $\begin{array}{l}\text { Cross-sectional } \\
\text { Chile, } 12.9 \text { y, grades 5-9, } \\
\text { boys and girls, } n=1271\end{array}$ & $\begin{array}{l}\text { System for the } \\
\text { Assessment of } \\
\text { Educational Quality }\end{array}$ & Questionnaire & $\begin{array}{l}\text { Sex, SES and student's learning } \\
\text { experience }\end{array}$ & $\begin{array}{l}\text { Those reporting } \leq 2 \text { hours/ } \\
\text { week of PA had significantly } \\
\text { lower performance in language, } \\
\text { maths and science, than those } \\
\text { reporting } \geq 4 \text { hours. } \S\end{array}$ \\
\hline Haapala et $\left.a\right|^{39} \ddagger$ & $\begin{array}{l}\text { Longitudinal } \\
\text { (5-year period) } \\
\text { Finland, } 7.7 \text { y, grades } 1-3 \text {, } \\
\text { boys and girls, } n=186\end{array}$ & $\begin{array}{l}\text { Nationally normed } \\
\text { reading achievement } \\
\text { test battery }\end{array}$ & PANIC-PAQ & $\begin{array}{l}\text { Sex, age, parental education and } \\
\text { the age, sex, parental education } \\
\text { and study group. }\end{array}$ & $\begin{array}{l}\text { Total PA and physically active } \\
\text { school transportation were related } \\
\text { to better academic } \\
\text { skills.§ }\end{array}$ \\
\hline Maureira Cid et al ${ }^{40}$ & $\begin{array}{l}\text { Cross-sectional } \\
\text { Chile, } 15.6 \text { y, grades 9-12, } \\
\text { boys and girls, } n=309\end{array}$ & School grades & Questionnaire & & $\begin{array}{l}\text { There was a significant relationship } \\
\text { between the number of weekdays } \\
\text { of PA and performance in } \\
\text { mathematics, history and sciences.§ }\end{array}$ \\
\hline
\end{tabular}


Table 3 Continued

\begin{tabular}{|c|c|c|c|c|c|}
\hline $\begin{array}{l}\text { Source and study } \\
\text { quality }\end{array}$ & $\begin{array}{l}\text { Study design and sample } \\
\text { characteristics (country, age } \\
\text { range/mean, grade, sex, n) }\end{array}$ & Outcome measured & PA measure & Adjustments for confounders & Main results \\
\hline Jaakkola et $a l^{16} \ddagger$ & $\begin{array}{l}\text { Longitudinal } \\
\text { (3-year period) } \\
\text { Finland, } 13.1 \text { y, grade } 7 \text {, } \\
\text { boys and girls, } \mathrm{n}=325\end{array}$ & School grades & HBSC & & $\begin{array}{l}\text { There was a significant longitudinal } \\
\text { weak association between } \\
\text { fundamental movement skills and } \\
\text { AA. However, self-reported PA } \\
\text { engagement was not prospectively } \\
\text { related to AA. } \dagger\end{array}$ \\
\hline Zhang et $a l^{43} \ddagger$ & $\begin{array}{l}\text { Cross-sectional } \\
\text { China, } 10.3 \text { y, grade } 5 \text {, } \\
\text { boys and girls, } n=2225\end{array}$ & School grades & IPAQ & $\begin{array}{l}\text { Sex, age, household income, } \\
\text { family structure, parents' } \\
\text { educational attainment, } \\
\text { participation in extracurricular } \\
\text { activities and health status. }\end{array}$ & $\begin{array}{l}\text { Minimal intensity PA (eg, walking) } \\
\text { was positively associated with } \\
\text { AA scores. After controlling the } \\
\text { analyses for school fixed effects, } \\
\text { MPA and VPA were not associated } \\
\text { with AA.§ }\end{array}$ \\
\hline $\begin{array}{l}\text { Kalantari and } \\
\text { Esmaeilzadeh et } a l^{49} \ddagger\end{array}$ & $\begin{array}{l}\text { Cross-sectional } \\
\text { Iran, } 15.7 \text { y, boys, } n=581\end{array}$ & School grades & PAQ-A & $\begin{array}{l}\text { Age, } \% \text { fat, pubertal } \\
\text { maturation and SES. }\end{array}$ & $\begin{array}{l}\text { After controlling for potential } \\
\text { confounders, PA was not } \\
\text { significantly correlated to } \\
\text { AA (cumulative grade point } \\
\text { averages). } \dagger\end{array}$ \\
\hline Kantomaa et $a l^{93} \ddagger$ & $\begin{array}{l}\text { Cross-sectional } \\
\text { Finland, } 16 \mathrm{y} \text {, } \\
\text { boys and girls, } \mathrm{n}=8061\end{array}$ & $\begin{array}{l}\text { School grades } \\
\text { (based on national } \\
\text { comparable grades of } \\
\text { the final assessment) }\end{array}$ & Questionnaire & $\begin{array}{l}\text { Mother's level of education and } \\
\text { self-rated health. }\end{array}$ & $\begin{array}{l}\text { High level of PA, with a reasonable } \\
\text { amount of time spent in sedentary } \\
\text { behaviour, such as media use, was } \\
\text { associated with good AA.§ }\end{array}$ \\
\hline Suchert et $a l^{44} \ddagger$ & $\begin{array}{l}\text { Longitudinal } \\
\text { (1-year period) } \\
\text { Germany, } 14.1 \mathrm{y} \text {, } \\
\text { boys and girls, } \mathrm{n}=1011\end{array}$ & School grades & Questionnaire & $\begin{array}{l}\text { Sex, age, type of school, AA at } \\
\text { baseline. }\end{array}$ & $\begin{array}{l}\text { Students who changed from non- } \\
\text { compliance to compliance with } \\
\text { PA guidelines attained better AA } \\
\text { and a greater improvement than } \\
\text { those meeting these guidelines } \\
\text { neither at baseline nor at follow-up } \\
\text { assessment.§}\end{array}$ \\
\hline
\end{tabular}

\footnotetext{
*Study of weak quality.

†The symbol means that in general there is no correlation/association between self-reported physical activity and academic achievement. ‡Study of strong quality.

$\S$ The symbol means that in general there is a positive correlation/association between self-reported physical activity and academic achievement. ПStudy of moderate quality.

** The symbol means that in general there is a negative correlation/association between self-reported physical activity and academic achievement.

AA, academic achievement; BMI, body mass index; HBSC, Health Behaviour in School-aged Children survey; IPAQ, International Physical Activity Questionnaire; MVPA, moderateto-vigorous physical activity; PA, physical activity; PANIC-PAQ, Physical Activity and Nutrition in Children-Physical Activity Questionnaire; PAQ-A, Physical Activity QuestionnaireAdolescents; PAQ-C, Physical Activity Questionnaire-Children; RCT, randomised control trial; SES, socioeconomic status; VPA, vigorous physical activity; $y$, years.
}

as a result of the intervention, did not increase or compromise students' academic achievement. ${ }^{47}$ A study performed among North Korean adolescents showed interesting results since VPA was positively correlated with academic achievement, but when undertaken $\geq 5$ times/week VPA was negatively correlated with academic achievement. ${ }^{51}$

\section{Cardiorespiratory fitness and academic achievement}

The description of the included studies reporting on the relationship between cardiorespiratory fitness and academic achievement is presented in table 4. Cardiorespiratory fitness has most often been measured using the Progressive Aerobic Cardiovascular Endurance Run and 1 mile test. From the 28 studies that have analysed the relationship between cardiorespiratory fitness and academic achievement, ${ }^{17} 3738444952-73$ it was verified that they generally supported the beneficial effect of cardiorespiratory fitness on students' academic achievement. However, in two of the studies, a significant association between cardiorespiratory fitness and academic achievement was not observed ${ }^{5671}$ after adjusting the analysis for potential confounders. In the four longitudinal studies, ${ }^{44586474}$ staying in the healthy cardiorespiratory fitness zone or improving cardiorespiratory fitness during the observational period was significantly related to better academic achievement, reinforcing prior research indicating that cardiorespiratory fitness has a significant and positive relationship with academic achievement. No pattern could be identified that included students' age. It is important to highlight that none of the studies of cardiorespiratory fitness observed a detrimental relationship with academic achievement.

\section{DISCUSSION}

Overall, the findings revealed that self-reported physical activity and cardiorespiratory fitness were consistently and positively associated with academic achievement. Objectively measured physical activity was inconsistently related to academic achievement. Although the results varied, physical activity does not have a detrimental effect on academic achievement.

The positive and significant association between cardiorespiratory fitness and academic achievement was shown in all reviewed studies, ${ }^{17} 37384952-6769-74$ although in two studies the relationship was only observed among girls, ${ }^{5272}$ and in two others the significant effect disappeared when potential confounders were included in the analysis. ${ }^{5671}$ The conclusion that cardiorespiratory fitness is associated with academic achievement was reinforced by the significant findings in the four longitudinal studies reviewed. ${ }^{44586474}$ 
Table 4 Description of the studies reporting the relationship between CRF and AA in children and adolescents

\begin{tabular}{|c|c|c|c|c|c|}
\hline $\begin{array}{l}\text { Source and study } \\
\text { quality }\end{array}$ & $\begin{array}{l}\text { Study design and sample } \\
\text { characteristics (country, } \\
\text { age range/mean, grade, } \\
\text { sex, } \mathrm{n} \text { ) }\end{array}$ & Outcome measured & CRF measure & $\begin{array}{l}\text { Adjustments for } \\
\text { confounders }\end{array}$ & Main results \\
\hline $\begin{array}{l}\text { Eveland-Sayers } \\
\text { et } a l^{2} \ddagger\end{array}$ & $\begin{array}{l}\text { Cross-sectional } \\
\text { USA, } 9.7 \text { y, grades } 3-5 \text {, } \\
\text { boys and girls, } n=134\end{array}$ & $\begin{array}{l}\text { TerraNova } \\
\text { Standardized } \\
\text { Academic } \\
\text { Achievement Test }\end{array}$ & 1 mile test & & $\begin{array}{l}\text { A positive relationship between CRF and } \\
\text { AA in math and language among girls was } \\
\text { observed. } \dagger \\
\text { There was no significant relationship among } \\
\text { boys.§}\end{array}$ \\
\hline Wittberg et $a l^{69} \neq$ & $\begin{array}{l}\text { Cross-sectional } \\
\text { USA, grade } 5 \text {, } \\
\text { boys and girls, } n=1941\end{array}$ & $\begin{array}{l}\text { The West Virginia } \\
\text { Educational } \\
\text { Standards Test }\end{array}$ & $\begin{array}{l}\text { PACER } \\
1 \text { mile test }\end{array}$ & Sex, BMI, SES. & $\begin{array}{l}\text { There were highly significant correlations } \\
\text { with small to medium effect sizes for both } \\
\text { girls' PACER and boys' } 1 \text { mile run with AA in } \\
\text { reading, math and science. }{ }^{\prime}\end{array}$ \\
\hline Du Toit et $a l^{60} q$ & $\begin{array}{l}\text { Cross-sectional } \\
\text { South Africa, } 10.8 \mathrm{y}, \\
\text { grades } 4-6, \\
\text { boys and girls, } n=212\end{array}$ & School grades & PACER & & $\begin{array}{l}\text { It was observed a positive relationship } \\
\text { between CRF and AA, with more significant } \\
\text { correlations found among girls than boys, and } \\
\text { among older boys and girls. } t\end{array}$ \\
\hline Edwards et $\left.a\right|^{38}$ & $\begin{array}{l}\text { Cross-sectional } \\
\text { USA, } 11-13 \text { y, } \\
\text { boys and girls, } n=694\end{array}$ & $\begin{array}{l}\text { Measures of } \\
\text { Academic Progress }\end{array}$ & PACER & $\begin{array}{l}\text { Sex, BMI, PA and meal price } \\
\text { status. }\end{array}$ & $\begin{array}{l}\text { Higher mile run performance was associated } \\
\text { with higher math scores. } t\end{array}$ \\
\hline de Greeff et $a l^{59 *}$ & $\begin{array}{l}\text { Cross-sectional } \\
\text { Netherlands, } 8.0 \mathrm{y} \text {, } \\
\text { grades } 2-3, \\
\text { boys and girls, } \mathrm{n}=544\end{array}$ & School grades & Eurofit & Sex, age and grade. & $\begin{array}{l}\text { Multilevel analysis showed positive } \\
\text { associations between CRF and math and } \\
\text { spelling. } \dagger\end{array}$ \\
\hline $\begin{array}{l}\text { Esteban-Cornejo } \\
\text { et } a l^{61 *}\end{array}$ & $\begin{array}{l}\text { Cross-sectional } \\
\text { Spain, } 10.2 \mathrm{y}, \\
\text { boys and girls, } \mathrm{n}=2038\end{array}$ & School grades & ALPHA & $\begin{array}{l}\text { Sex, age, city, pubertal status } \\
\text { and maternal education, other } \\
\text { fitness variables. }\end{array}$ & $\begin{array}{l}\text { CRF was associated with AA in math and } \\
\text { language, even after adjustment for fitness } \\
\text { and fatness indicators. } t\end{array}$ \\
\hline Hansen et $a l^{17 *}$ & $\begin{array}{l}\text { Cross-sectional } \\
\text { USA, } 7.8 \text { y, } 2-4 \text { grades, } \\
\text { boys and girls, } n=688\end{array}$ & $\begin{array}{l}\text { Standardized } \\
\text { Composite Academic } \\
\text { Test }\end{array}$ & PACER & $\begin{array}{l}\text { Sex, grade, race, ethnicity, } \\
\text { mother's education, household } \\
\text { income and BMI. }\end{array}$ & $\begin{array}{l}\text { CRF had a significant quadratic association } \\
\text { with both spelling and math achievement. } \dagger\end{array}$ \\
\hline Janak et $a^{62} \ddagger$ & $\begin{array}{l}\text { Cross-sectional } \\
\text { USA, 3-12 y, } \\
\text { boys and girls, } n=1370632\end{array}$ & $\begin{array}{l}\text { Texas Assessment of } \\
\text { Knowledge and Skills }\end{array}$ & PACER & Grade and SES. & $\begin{array}{l}\text { Positive moderate-to-strong associations were } \\
\text { observed for CRF AA. After adjustment for SES, } \\
\text { the magnitude of effect for CRF and AA was } \\
\text { small. } \dagger\end{array}$ \\
\hline Sardinha et $a l^{63 *}$ & $\begin{array}{l}\text { Cross-sectional } \\
\text { Portugal, } 12.3 \mathrm{y}, \text { grade } 7, \\
\text { boys and girls, } \mathrm{n}=1531\end{array}$ & School grades & PACER & Sex and cohorts. & $\begin{array}{l}\text { CR fit students, compared with unfit students } \\
\text { had significantly higher odds for having high } \\
\text { AA. }+\end{array}$ \\
\hline Torrijos-Niño et $a^{66 *}$ & $\begin{array}{l}\text { Cross-sectional } \\
\text { Spain, } 9.5 \mathrm{y}, \\
\text { boys and girls, } \mathrm{n}=893\end{array}$ & School grades & PACER & $\begin{array}{l}\text { Age, parent's education, } \\
\text { fitness and BMI. }\end{array}$ & $\begin{array}{l}\text { AA scores were positively related to CRF } \\
\text { levels. } t\end{array}$ \\
\hline
\end{tabular}


Table 4 Continued

\begin{tabular}{|c|c|c|c|c|c|}
\hline $\begin{array}{l}\text { Source and study } \\
\text { quality }\end{array}$ & $\begin{array}{l}\text { Study design and sample } \\
\text { characteristics (country, } \\
\text { age range/mean, grade, } \\
\text { sex, } \mathrm{n} \text { ) }\end{array}$ & Outcome measured & CRF measure & $\begin{array}{l}\text { Adjustments for } \\
\text { confounders }\end{array}$ & Main results \\
\hline Srikanth et $a / 65 *$ & $\begin{array}{l}\text { Cross-sectional } \\
\text { USA, } 12.4 \mathrm{y}, \text { grades } 7-8 \text {, } \\
\text { boys and girls, } \mathrm{n}=1211\end{array}$ & $\begin{array}{l}\text { Texas Assessment of } \\
\text { Knowledge and Skills }\end{array}$ & PACER & $\begin{array}{l}\text { SES, like reading, health } \\
\text { perception and BMI. }\end{array}$ & $\begin{array}{l}\text { Regression analyses revealed that CRF was a } \\
\text { consistent predictor of the students' AA in in } \\
\text { math and reading. } t\end{array}$ \\
\hline Aguilar et $a l^{71 *}$ & $\begin{array}{l}\text { Cross-sectional } \\
\text { Chile, } 12.1 \text { y, grade } 7 \text {, } \\
\text { boys and girls, } n=395\end{array}$ & School grades & PACER & $\begin{array}{l}\text { Age, BMI, SES, PA, parental } \\
\text { education and screen time. }\end{array}$ & $\begin{array}{l}\text { Good CRF levels was associated with high } \\
\text { language and mean AA grades; however, after } \\
\text { adjusting for other potential confounders, } \\
\text { these associations disappear. } § \S\end{array}$ \\
\hline Bass et $a l^{57 *}$ & $\begin{array}{l}\text { Cross-sectional } \\
\text { USA, } 13.1 \mathrm{y}, \text { grades } 6-8 \text {, } \\
\text { boys and girls, } \mathrm{n}=838\end{array}$ & $\begin{array}{l}\text { Illinois Standardized } \\
\text { Achievement Test }\end{array}$ & PACER & Age and SES & $\begin{array}{l}\text { Boys and girls in the CRF zone (HFZ) were } \\
\text { more likely to pass in their math and reading } \\
\text { tests. } t\end{array}$ \\
\hline Andersen et $\left.a\right|^{53} \emptyset$ & $\begin{array}{l}\text { Cross-sectional } \\
\text { Denmark, } 13-15 y \text {, } \\
\text { boys and girls, } n=1119\end{array}$ & $\begin{array}{l}\text { Standardised test } \\
\text { (mandatory exams) }\end{array}$ & Cycle ergometer & SES and ethnicity. & $\begin{array}{l}\text { Students with higher CRF perform better } \\
\text { academically than students with lower CRF. } \dagger\end{array}$ \\
\hline $\begin{array}{l}\text { Castro and Oliveira } \\
54\end{array}$ & $\begin{array}{l}\text { Cross-sectional } \\
\text { Brazil, } 15-18 \mathrm{y}, \\
\text { boys and girls, } \mathrm{n}=326\end{array}$ & School grades & 1 mile test & Age and sex & $\begin{array}{l}\text { CRF was associated with AA. Being unfit } \\
\text { doubles the likelihood of poor AA. } t\end{array}$ \\
\hline $\begin{array}{l}\text { Kalantari and } \\
\text { Esmaeilzadeh }\end{array}$ & $\begin{array}{l}\text { Cross-sectional } \\
\text { Iran, } 15.7 \text { y, boys, } n=580\end{array}$ & School grades & 1 mile test & $\begin{array}{l}\text { Age, adiposity, pubertal } \\
\text { maturation and SES. }\end{array}$ & $\begin{array}{l}\text { CRF is significantly correlated to better AA in } \\
\text { the adolescent boys. } t\end{array}$ \\
\hline Kao et $a l^{55} \ddagger$ & $\begin{array}{l}\text { Cross-sectional } \\
\text { USA, } 10.1 \mathrm{y} \\
\text { boys and girls, } \mathrm{n}=79\end{array}$ & $\begin{array}{l}\text { California Standards } \\
\text { Test }\end{array}$ & $\begin{array}{l}\text { Graded exercise } \\
\text { test }\end{array}$ & Age, sex, grade, SES, IQ & $\begin{array}{l}\text { CRF was associated with greater mathematics } \\
\text { performance in the category of algebraic } \\
\text { functions. } t\end{array}$ \\
\hline $\begin{array}{l}\text { Olivares and García- } \\
\text { Rubi }^{56} q\end{array}$ & $\begin{array}{l}\text { Cross-sectional } \\
\text { Chile, grade } 8 \text {, } \\
\text { boys and girls, } n=18746\end{array}$ & Standardised tests & $\begin{array}{l}\text { Chilean } \\
\text { Standardized } \\
\text { System for the } \\
\text { Assessment of } \\
\text { Educational } \\
\text { Quality test }\end{array}$ & $\begin{array}{l}\text { Age, sex, SES, region and type } \\
\text { of school, fitness components }\end{array}$ & $\begin{array}{l}\text { CRF was not associated with AA if fatness and } \\
\text { other fitness components were included in the } \\
\text { model.§}\end{array}$ \\
\hline $\begin{array}{l}\text { de Almeida Santana } \\
\text { et } a P^{52} q\end{array}$ & $\begin{array}{l}\text { Cross-sectional } \\
\text { Brazil, } 10-13 \text { y, grades 5-6, } \\
\text { boys and girls, } n=392\end{array}$ & Standardised test & PACER & $\begin{array}{l}\text { Absolute skinfold thickness, } \\
\text { BMI-percentiles and SES. }\end{array}$ & $\begin{array}{l}\text { CRF was associated with higher academic } \\
\text { achievement among girls. } \dagger \\
\text { No significant association was found among } \\
\text { boys. } \S\end{array}$ \\
\hline Sardinha et al ${ }^{64 *}$ & $\begin{array}{l}\text { Longitudinal } \\
\text { (3-year period) } \\
\text { Portugal, } 11.3 \text { years, } \\
\text { grades } 6-7 \text {, } \\
\text { boys and girls, } n=1286\end{array}$ & School grades & PACER & $\begin{array}{l}\text { Sex, BMI z-score, AA at } \\
\text { baseline and schools. }\end{array}$ & $\begin{array}{l}\text { Consistently CRF fit and improvements in CRF } \\
\text { were prospectively associated with better AA } \\
\text { in languages. } t\end{array}$ \\
\hline Suchert et $a l^{44} \ddagger$ & $\begin{array}{l}\text { Longitudinal } \\
\text { (1-year period) } \\
\text { Germany, } 14.1 \mathrm{y} \text {, } \\
\text { boys and girls, } \mathrm{n}=1011\end{array}$ & School grades & $\begin{array}{l}\text { PACER } \\
\text { (shuttle run test) }\end{array}$ & $\begin{array}{l}\text { Sex, age, type of school, AA at } \\
\text { baseline. }\end{array}$ & High CRF predicted higher AA. $\dagger$ \\
\hline
\end{tabular}

*Study of strong quality.

†The symbol means that in general there is a positive correlation/association between cardiorespiratory fitness and academic achievement.

¥Study of moderate quality.

§The symbol means that in general there is no correlation/association between cardiorespiratory fitness and academic achievement.

IStudy of weak quality.

AA, academic achievement; ALPHA, Assessing Levels of Physical Activity; BMI, body mass index; CRF, cardiorespiratory fitness; HFZ, healthy fitness zone; PA, physical activity;

PACER, Progressive Aerobic Cardiovascular Endurance Run, which is part of Fitnessgram; SES, socioeconomic status; $y$, years.

\section{Possible mechanisms for the association between cardiorespiratory fitness and academic achievement}

There are several potential explanations for the association between cardiorespiratory fitness and academic achievement. First, students with better academic achievement may be better oriented for success, and therefore might attempt to achieve success in both academics and physical fitness. ${ }^{75}$ A second category of mechanisms may relate to cardiorespiratory fitness effects neural substrates. Cardiorespiratory fitness enhances brain structure and function underlying students' concentration and memory which, in turn, could relate to academic achievement. Cardiorespiratory fitness increases the density of neuronal synapses, ${ }^{76}$ the vasculature in the cerebral cortex and the recruitment of neural resources related to the effectiveness of adapting to task demands and fatigue. ${ }^{4}$ Cardiorespiratory fitness also enhances the integrity of white matter tracts in the brain during childhood, which may be one pathway to improve the cognition. ${ }^{577}$ Furthermore, at a biochemical level, cardiorespiratory fitness may enhance the synthesis of brain-derived neurotrophic factor (BDNF), and an increase in BDNF is associated with increases in neurogenesis. 77879

What is the association between physical activity (objective and self-reported) and academic achievement?

We found a positive association between self-reported physical activity and academic achievement in most studies, ${ }^{33} 36-4651$ which extends previous findings that assessed physical activity 
through self-reported questionnaires. ${ }^{13} 80$ However, 6 of 11 studies that objectively measured physical activity showed no relationship with academic achievement ${ }^{17} 293032-34$ and one showed a negative relationship. ${ }^{19}$ This negative association was only observed when analyses were adjusted for potential confounders including a computed z-score from cardiorespiratory and motor fitness tests.

The studies included in this review did not account for the time of day when physical activity was performed. This is an important consideration because some of the benefits that are related to physical activity on academic achievement may be acute, ${ }^{81}$ and therefore physical activity should be performed within the school environment. ${ }^{82}$ This lack of consistency when using self-reported versus objectively assessed physical activity associated with academic achievement has been previously discussed. $^{338283}$ Indeed, Syväoja et $a l^{33}$ observed that self-reported, but not objectively measured physical activity, was associated with academic achievement. There are a numerous possibilities for this inconsistency; younger children tend to overestimate their physical activity relative to objective measures. ${ }^{84}$ Interestingly, it was previously reported that those children overestimating physical activity were also those presenting with higher academic achievement. ${ }^{33}$

Accelerometers provide several advantages in assessing physical activity, but they are not free of limitations. ${ }^{85}$ Accelerometers are used during a short period of time that may not fully represent the typical physical activity patterns. Also, there are limitations when assessing cycling, swimming or other activities that are not reflected in typical activity counts (eg, skill-specific activities related with agility, balance, control and coordination). ${ }^{82} 84$ Indeed, some activities that do not accumulate activity counts may improve motor control, and this may potentially contribute to improved academic performance via opportunities to interact with the environment and rehearse language and cognitive skills. ${ }^{86}$ Children with better motor control performance have better academic achievement. ${ }^{86} 87$ This is consistent with the results that demonstrate interwoven associations between motor control and cognitive development, showing that many brain areas are involved in both motor control and cognitive processes. ${ }^{88} 89$

Based on the inconsistent results observed for objective and self-reported physical activity, it is clear that the relationship between physical activity and academic achievement is not yet conclusive. ${ }^{1380}$ It is necessary to reinforce that self-reported physical activity methods possess several limitations in terms of reliability and validity. ${ }^{90}$ Self-reported physical activity may be problematic in children and adolescents because they are less time conscious than adults and tend to engage in physical activity in sporadic periods with different intensities rather than consistent patterns. ${ }^{91}$ Besides compromised reliability, the validity of measures may be affected in children and adolescents who feel compelled to respond in a socially desirable manner. Children and adolescents may have difficulties in recalling physical activity and in understanding and responding to items within the questionnaire. ${ }^{92}$ In addition, in some instances, self-reported physical activity measures only assess the frequency, the intensity or the duration, which limits the conclusions that may be drawn regarding its relationship with academic achievement. As a result, to report that physical activity is associated with academic achievement based mainly on self-reported physical activity should be made with caution, and the assumption that participation in physical activity positively affects academic achievement or the way that children behave and learn in school has yet to be validated. ${ }^{15}$ The present study further extends this conclusion by reviewed studies using objective and subjective measures of physical activity.
Are there differences in how physical activity influences academic performance at different ages?

Since this review included the entire spectrum of school-aged children, ranging from 6 to 18 years, which is novel compared with previous reviews, ${ }^{13} 1480$ results could point to differential associations between children and adolescents. In regard to the association between objective physical activity and academic achievement, positive associations were observed with students older than 10 years, ${ }^{27283135}$ whereas this was not seen in younger students. ${ }^{172932}$ Perhaps during the early years of schooling, parents' education, socioeconomic status or time devoted to studying are some of the main factors that explain the students' academic success. In general, based on this review, it is not possible to conclude any relationship with age, because none of the studies were designed to examine the effect of age and most accounted for age in their analysis.

\section{Strengths and limitations}

The main strength of this review arises from the systematisation of studies on associations with cardiorespiratory fitness and physical activity, with a further differentiation between objective and self-reported physical activity. Previous reviews ${ }^{13} 80$ did not differentiate between objective and self-reported physical activity. The present review included school-aged children and adolescents from 6 to 18 years, which represents the entire primary, middle and secondary education in most countries.

This review has limitations that restrict the ability to draw causal inferences. Although the studies were assessed according to their methodological quality, ${ }^{26}$ they were not ranked or weighted, consequently, findings from studies with weaker quality, and smaller sample sizes were given equal weight relative to findings from studies with stronger research designs and larger sample sizes. Academic achievement was measured based on school grades or standardised tests. School grades given by teacher are subject to bias because teachers' evaluation can also reflect other constructs, such as students' behaviour. Thus, it might be difficult to compare results from school grades and standardised tests.

We could not apply our methods to any interventions studies; as most studies included were cross-sectional, we must limit our conclusions. Another limitation is the fact that some studies were adjusted for potential confounders, and others were not. Furthermore, to reinforce the evidence observed in the present study, future work should endeavour to perform meta-analytic analyses. Such meta-analyses were not possible herein, as the studies reviewed possessed a wide range of metrics and outcomes, which precluded the possibility of creating a coherent analytical strategy.

\section{CONCLUSION}

Our systematic review revealed an association between cardiorespiratory fitness and academic achievement. There was inconsistency in the results of studies that examined the association between physical activity and academic achievement; this was particularly the case when physical activity was measured by accelerometry.

\section{What are the findings?}

Studies in neuroscience have shown that physical activity and cardiorespiratory fitness are related to brain structure and function. 
How might it impact on clinical practice in the future?

- There is a positive relationship between cardiorespiratory fitness and academic achievement.

- The results were inconsistent regarding the relationship between objective measured physical activity and academic achievement.

- Studies reporting the relationship between self-reported physical activity and academic achievement reported positive associations between physical activity and academic achievement.

Contributors AM, DAS and LBS conceived the study, and AM and DAS developed a systematic review protocol. AM and DAS conducted the literature search and selected the studies based on the title and the abstract and extracted and coded the data from all studies. Study outcomes were summarised by AM, DAS and LBS. They wrote the initial draft of the manuscript, and $\mathrm{CHH}$ made significant revisions and contributions. All authors read and approved the final manuscript.

Funding DAS is supported by a scholarship from the Portuguese Foundation for Science and Technology (grant: SFRH/BPD/92462/2013).

\section{Competing interests None declared.}

\section{Provenance and peer review Not commissioned; externally peer reviewed.}

(c) Article author(s) (or their employer(s) unless otherwise stated in the text of the article) 2017. All rights reserved. No commercial use is permitted unless otherwise expressly granted.

\section{REFERENCES}

1 Janssen I, Leblanc AG. Systematic review of the health benefits of physical activity and fitness in school-aged children and youth. Int J Behav Nutr Phys Act 2010;7:40.

2 Andersen LB, Sardinha LB, Froberg K, et al. Fitness, fatness and clustering of cardiovascular risk factors in children from Denmark, Estonia and Portugal: the European Youth Heart Study. Int J Pediatr Obes 2008;3:58-66.

3 Anderssen SA, Cooper AR, Riddoch C, et al. Low cardiorespiratory fitness is a strong predictor for clustering of cardiovascular disease risk factors in children independent of country, age and sex. Eur J Cardiovasc Prev Rehabil 2007;14:526-31.

4 Chaddock L, Erickson KI, Prakash RS, et al. A functional MRI investigation of the association between childhood aerobic fitness and neurocognitive control. Biol Psychol 2012;89:260-8.

5 Chaddock-Heyman L, Erickson Kl, Kienzler C, et al. The role of aerobic fitness in cortical thickness and mathematics achievement in preadolescent children. PLoS One 2015;10:e0134115.

6 Schaeffer DJ, Krafft CE, Schwarz NF, et al. An 8-month exercise intervention alters frontotemporal white matter integrity in overweight children. Psychophysiology 2014;51:728-33.

7 Cotman CW, Berchtold NC, Christie LA. Exercise builds brain health: key roles of growth factor cascades and inflammation. Trends Neurosci 2007;30:464-72.

8 Hillman $\mathrm{CH}$, Erickson KI, Kramer AF. Be smart, exercise your heart: exercise effects on brain and cognition. Nat Rev Neurosci 2008;9:58-65.

9 Chaddock L, Hillman CH, Pontifex MB, et al. Childhood aerobic fitness predicts cognitive performance one year later. J Sports Sci 2012;30:421-30.

10 Hillman CH, Castelli DM, Buck SM. Aerobic fitness and neurocognitive function in healthy preadolescent children. Med Sci Sports Exerc 2005;37:1967-74.

11 Monti JM, Hillman CH, Cohen NJ. Aerobic fitness enhances relational memory in preadolescent children: the FITKids randomized control trial. Hippocampus 2012;22:1876-82.

12 Moore RD, Wu CT, Pontifex MB, et al. Aerobic fitness and intra-individual variability of neurocognition in preadolescent children. Brain Cogn 2013;82:43-57.

13 Esteban-Cornejo I, Tejero-Gonzalez CM, Sallis JF, et al. Physical activity and cognition in adolescents: A systematic review. J Sci Med Sport 2015;18:534-9.

14 Rasberry CN, Lee SM, Robin L, et al. The association between school-based physical activity, including physical education, and academic performance: a systematic review of the literature. Prev Med 2011;52 Suppl 1:S10-S20.

15 Donnelly JE, Hillman CH, Castelli D, et al. Physical activity, fitness, cognitive function, and academic achievement in children: a systematic review. Med Sci Sports Exerc 2016;48:1197-222.

16 Jaakkola T, Hillman C, Kalaja S, et al. The associations among fundamental movement skills, self-reported physical activity and academic performance during junior high school in Finland. J Sports Sci 2015;33:1719-29.

17 Hansen DM, Herrmann SD, Lambourne K, et al. Linear/nonlinear relations of activity and fitness with children's academic achievement. Med Sci Sports Exerc 2014;46:2279-85.
18 Tremblay MS, Inman JW, Willms JD. The relationship between physical activity, self-esteem, and academic achievement in 12-year-old children. Pediatr Exerc Sci 2000;12:312-23.

19 Esteban-Cornejo I, Tejero-González CM, Martinez-Gomez D, et al. Objectively measured physical activity has a negative but weak association with academic performance in children and adolescents. Acta Paediatr 2014;103:e501-e506.

20 Adamo KB, Prince SA, Tricco AC, et al. A comparison of indirect versus direct measures for assessing physical activity in the pediatric population: a systematic review. Int J Pediatr Obes 2009;4:2-27.

21 Basterfield L, Adamson AJ, Parkinson KN, et al. Surveillance of physical activity in the UK is flawed: validation of the Health Survey for England Physical Activity Questionnaire. Arch Dis Child 2008;93:1054-8.

22 Moher D, Shamseer L, Clarke M, et al. Preferred reporting items for systematic review and meta-analysis protocols (PRISMA-P) 2015 statement. Syst Rev 2015;4:1.

23 Álvarez-Bueno C, Pesce C, Cavero-Redondo I, et al. Association of physical activity with cognition, metacognition and academic performance in children and adolescents: a protocol for systematic review and meta-analysis. BMJ Open 2016;6:e011065

24 Hogg R, Tanis E, Zimmerman D. Probability and statistical inference. Upper Saddle River, NJ: Pearson, 2015.

25 Troiano RP. A timely meeting: objective measurement of physical activity. Med Sci Sports Exerc 2005;37:S487-S489.

26 Thomas BH, Ciliska D, Dobbins M, et al. A process for systematically reviewing the literature: providing the research evidence for public health nursing interventions. Worldviews Evid Based Nurs 2004;1:176-84.

27 Booth JN, Leary SD, Joinson C, et al. Associations between objectively measured physical activity and academic attainment in adolescents from a UK cohort. Br J Sports Med 2014;48:265-70.

28 Kwak L, Kremers SP, Bergman P, et al. Associations between physical activity, fitness, and academic achievement. J Pediatr 2009;155:914-8.

29 Lambourne K, Hansen DM, Szabo AN, et al. Indirect and direct relations between aerobic fitness, physical activity, and academic achievement in elementary school students. Ment Health Phys Act 2013;6:165-71.

30 LeBlanc MM, Martin CK, Han $\mathrm{H}$, et al. Adiposity and physical activity are not related to academic achievement in school-aged children. J Dev Behav Pediatr 2012;33:486-94.

31 Maher C, Lewis L, Katzmarzyk PT, et al. The associations between physical activity, sedentary behaviour and academic performance. J Sci Med Sport 2016;19:1004-9.

32 Pindus DM, Drollette ES, Scudder MR, et al. Moderate-to-vigorous physical activity, indices of cognitive control, and academic achievement in preadolescents. J Pediatr 2016;173:136-42.

33 Syväoja HJ, Kantomaa MT, Ahonen T, et al. Physical activity, sedentary behavior, and academic performance in Finnish children. Med Sci Sports Exerc 2013;45:2098-104.

34 Van Dijk ML, De Groot RH, Savelberg HH, et al. The association between objectively measured physical activity and academic achievement in dutch adolescents: findings from the GOALS study. I Sport Exerc Psychol 2014;36:460-73.

35 Resaland GK, Aadland E, Moe VF, et al. Effects of physical activity on schoolchildren's academic performance: the Active Smarter Kids (ASK) cluster-randomized controlled trial. Prev Med 2016;91:322-8.

36 Burrows R, Correa-Burrows $P$, Orellana $Y$, et al. Scheduled physical activity is associated with better academic performance in Chilean school-age children.J Phys Act Health 2014;11:1600-6.

37 Dwyer T, Sallis JF, Blizzard L, et al. Relation of academic performance to physical activity and fitness in children. Pediatr Exerc Sci 2001;13:225-37.

38 Edwards JU, Mauch L, Winkelman MR. Relationship of nutrition and physical activity behaviors and fitness measures to academic performance for sixth graders in a midwest city school district. J Sch Health 2011;81:65-73.

39 Haapala EA, Poikkeus AM, Kukkonen-Harjula K, et al. Associations of physical activity and sedentary behavior with academic skills--a follow-up study among primary school children. PLoS One 2014;9:e107031.

40 Maureira Cid F, Mallea D I, Foos Espuña P, et al. Relation of the practice of physical activity and the academic performance in students of santiago of chile. Revista Ciencias de la Actividad Física UCM 2014;15:43-50.

41 Morales J, Pellicer-Chenoll M, García-Masso X, et al. Relation between physical activity and academic performance in 3 rd-year secondary education students. Percept Mot Skills 2011;113:539-46.

42 Stevens TA, To Y, Stevenson SJ, et al. The importance of physical activity and physical education in the prediction of academic achievement. Journal of Sport Behavior 2008;31:368-88.

43 Zhang Y, Zhang D, Jiang Y, et al. Association between physical activity and teacherreported academic performance among fifth-graders in Shanghai: a quantile regression. PLoS One 2015;10:e0115483.

44 Suchert V, Hanewinkel R, Isensee B. Longitudinal relationships of fitness, physical activity, and weight status with academic achievement in adolescents. I Sch Health 2016;86:734-41.

45 Kantomaa MT, Stamatakis E, Kankaanpää A, et al. Associations of physical activity and sedentary behavior with adolescent academic achievement. J Res Adolesc 2016;26:432-42. 
46 Kristjánsson AL, Sigfúsdóttir ID, Allegrante JP. Health behavior and academic achievement among adolescents: the relative contribution of dietary habits, physical activity, body mass index, and self-esteem. Health Educ Behav 2010;37:51-64.

47 Ahamed Y, Macdonald H, Reed K, et al. School-based physical activity does not compromise children's academic performance. Med Sci Sports Exerc 2007;39:371-6.

48 Daley AJ, Ryan J. Academic performance and participation in physical activity by secondary school adolescents. Percept Mot Skills 2000;91:531-4.

49 Kalantari HA, Esmaeilzadeh S. Association between academic achievement and physical status including physical activity, aerobic and muscular fitness tests in adolescent boys. Environ Health Prev Med 2016;21:27-33.

50 Ccw Y, Chan S, Cheng F, et al. Are physical activity and academic performance compatible? Academic achievement, conduct, physical activity and self-esteem of Hong Kong Chinese primary school children. Educational Studies 2006;32:331-41.

51 So WY. Association between physical activity and academic performance in Korean adolescent students. BMC Public Health 2012;12:258.

52 de Almeida Santana CC, Farah BQ, de Azevedo LB, et al. Associations between cardiorespiratory fitness and overweight with academic performance in 12-year-old Brazilian children. Pediatr Exerc Sci 2017;29:220-7.

53 Andersen MP, Mortensen RN, Vardinghus-Nielsen $\mathrm{H}$, et al. Association between physical fitness and academic achievement in a cohort of danish school pupils. J Sch Health 2016;86:686-95.

54 Castro F, Oliveira AC. Association between health-related physical fitness and academic performance in adolescents. Rev Bras Cineantropom Hum 2016;18:441-9.

55 Kao SC, Westfall DR, Parks AC, et al. Muscular and aerobic fitness, working memory, and academic achievement in children. Med Sci Sports Exerc 2016.

56 Olivares PR, García-Rubio J. Associations between different components of fitness and fatness with academic performance in Chilean youths. PeerJ 2016;4:e2560.

57 Bass RW, Brown DD, Laurson KR, et al. Physical fitness and academic performance in middle school students. Acta Paediatr 2013;102:832-7.

58 Chen LJ, Fox KR, Ku PW, et al. Fitness change and subsequent academic performance in adolescents. J Sch Health 2013;83:631-8.

59 de Greeff JW, Hartman E, Mullender-Wijnsma MJ, et al. Physical fitness and academic performance in primary school children with and without a social disadvantage. Health Educ Res 2014;29:853-60.

60 Du Toit D, Pienaar AE, Truter L. Relationship between physical fitness and academic performance in South African children. South African Journal for Research in Sport, Physical Education \& Recreation 2011;33:23-35.

61 Esteban-Cornejo I, Tejero-González CM, Martinez-Gomez D, et al. Independent and combined influence of the components of physical fitness on academic performance in youth. J Pediatr 2014;165:306-12.

62 Janak JC, Gabriel KP, Oluyomi AO, et al. The association between physical fitness and academic achievement in Texas state house legislative districts: an ecologic study. J Sch Health 2014;84:533-42.

63 Sardinha LB, Marques A, Martins S, et al. Fitness, fatness, and academic performance in seventh-grade elementary school students. BMC Pediatr 2014;14:176.

64 Sardinha LB, Marques A, Minderico C, et al. Longitudinal relationship between cardiorespiratory fitness and academic achievement. Med Sci Sports Exerc 2016:48:839-44.

65 Srikanth S, Petrie TA, Greenleaf C, et al. The relationship of physical fitness, self-beliefs, and social support to the academic performance of middle school boys and girls. J Early Adolesc 2015;35:353-77.

66 Torrijos-Niño C, Martínez-Vizcaíno V, Pardo-Guijarro MJ, et al. Physical fitness, obesity, and academic achievement in schoolchildren. J Pediatr 2014;165:104-9.

67 Van Dusen DP, Kelder SH, Kohl HW, et al. Associations of physical fitness and academic performance among schoolchildren. J Sch Health 2011;81:733-40.

68 Welk GJ, Jackson AW, Morrow JR, et al. The association of health-related fitness with indicators of academic performance in Texas schools. Res Q Exerc Sport 2010;81:S16-S23.
69 Wittberg R, Cottrell LA, Davis CL, et al. Aerobic fitness thresholds associated with fifth grade academic achievement. Am J Health Educ 2010;41:284-91.

70 Wittberg RA, Northrup KL, Cottrel L. Children's physical fitness and academic performance. Am J Health Educ 2009:40:30-6.

71 Aguilar MM, Vergara FA, Velásquez EJ, et al. Screen time impairs the relationship between physical fitness and academic attainment in children. J Pediatr 2015;91:339-45.

72 Eveland-Sayers BM, Farley RS, Fuller DK, et al. Physical fitness and academic achievement in elementary school children. J Phys Act Health 2009;6:99-104.

73 Castelli DM, Hillman CH, Buck SM, et al. Physical fitness and academic achievement in third- and fifth-grade students. J Sport Exerc Psychol 2007;29:239-52.

74 Wittberg RA, Northrup KL, Cottrell LA. Children's aerobic fitness and academic achievement: a longitudinal examination of students during their fifth and seventh grade years. Am J Public Health 2012;102:2303-7.

75 Thøgersen-Ntoumani C, Ntoumanis $\mathrm{N}$. The role of self-determined motivation in the understanding of exercise-related behaviours, cognitions and physical self-evaluations. J Sports Sci 2006;24:393-404.

76 Kramer AF, Colcombe $\mathrm{S}$, Erickson $\mathrm{K}$, et al. Effects of aerobic fitness training on human cortical function: a proposal. J Mol Neurosci 2002;19:227-31.

77 Chaddock-Heyman L, Erickson Kl, Holtrop JL, et al. Aerobic fitness is associated with greater white matter integrity in children. Front Hum Neurosci 2014;8.

78 Erickson KI, Voss MW, Prakash RS, et al. Exercise training increases size of hippocampus and improves memory. Proc Natl Acad Sci U S A 2011;108:3017-22.

79 Vaynman S, Ying Z, Gomez-Pinilla F. Hippocampal BDNF mediates the efficacy of exercise on synaptic plasticity and cognition. Eur J Neurosci 2004;20:2580-90.

80 Singh A, Uijtdewilligen L, Twisk JW, et al. Physical activity and performance at school: a systematic review of the literature including a methodological quality assessment. Arch Pediatr Adolesc Med 2012;166:49-55.

81 Hillman $\mathrm{CH}$, Pontifex MB, Raine LB, et al. The effect of acute treadmill walking on cognitive control and academic achievement in preadolescent children. Neuroscience 2009;159:1044-54.

82 Shephard RJ. Physical activity of children and academic achievement. Med Sci Sports Exerc 2014;46:840

83 Syväoja HJ, Kantomaa MT, Ahonen T, et al. Response. Med Sci Sports Exerc 2014;46:841.

84 Corder K, van Sluijs EM, McMinn AM, et al. Perception versus reality awareness of physical activity levels of British children. Am J Prev Med 2010;38:1-8.

85 Pedišić Ž, Bauman A. Accelerometer-based measures in physical activity surveillance: current practices and issues. Br J Sports Med 2015;49:219-23.

86 Iverson JM. Developing language in a developing body: the relationship between motor development and language development. J Child Lang 2010;37:229-61.

87 Westendorp M, Hartman E, Houwen S, et al. The relationship between gross motor skills and academic achievement in children with learning disabilities. Res Dev Disabil 2011;32:2773-9.

88 Diamond A. Close interrelation of motor development and cognitive development and of the cerebellum and prefrontal cortex. Child Dev 2000;71:44-56.

89 Best JR. Effects of physical activity on children's executive function: contributions of experimental research on Aerobic exercise. Dev Rev 2010;30:331-51.

90 Shephard RJ. Limits to the measurement of habitual physical activity by questionnaires. Br J Sports Med 2003;37:197-206.

91 Bailey RC, Olson J, Pepper SL, et al. The level and tempo of children's physical activities: an observational study. Med Sci Sports Exerc 1995:27:1033-41.

92 Chinapaw MJ, Mokkink LB, van Poppel MN, et al. Physical activity questionnaires for youth: a systematic review of measurement properties. Sports Med 2010;40:539-63.

93 Kantomaa MT, Stamatakis E, Kankaanpää A, et al. Physical activity and obesity mediate the association between childhood motor function and adolescents' academic achievement. Proc Natl Acad Sci U S A 2013;110:1917-22. 
How does academic achievement relate to cardiorespiratory fitness, self-reported physical activity and objectively reported physical activity: a systematic review in children and adolescents aged $6-18$ years

Adilson Marques, Diana A Santos, Charles H Hillman and Luís B Sardinha

Br J Sports Med published online October 14, 2017

Updated information and services can be found at:

http://bjsm.bmj.com/content/early/2017/10/14/bjsports-2016-097361

These include:

References This article cites 90 articles, 7 of which you can access for free at: http://bjsm.bmj.com/content/early/2017/10/14/bjsports-2016-097361 \#BIBL

Email alerting Receive free email alerts when new articles cite this article. Sign up in the service box at the top right corner of the online article.

\section{Notes}

To request permissions go to:

http://group.bmj.com/group/rights-licensing/permissions

To order reprints go to:

http://journals.bmj.com/cgi/reprintform

To subscribe to BMJ go to:

http://group.bmj.com/subscribe/ 